\title{
Andropov's Gamble: Samantha Smith and Soviet Soft Power
}

\section{Anton Fedyashin}

\section{Introduction}

On a November evening in 1982, a ten-year-old fifth-grader from Manchester, Maine — population just above two thousand - became concerned about world peace under the impression of news stories about the Soviet nuclear threat. To alleviate her daughter's fears, Jane Smith sat down with Samantha to read a Time magazine article about Yuri Andropov who had just succeeded Leonid Brezhnev as General Secretary of the CPSU. The introductory paragraph read: "When Joseph Conrad wrote about the place, he called his novel Under Western Eyes because he wanted his readers to understand that his history was told by an outsider, meaning that no non-Russian could ever hope to see into that particular heart of darkness with any clarity or certainty. It is the same now. With Leonid Brezhnev gone, where are Western eyes to look, at the man or at the space he left, for an understanding of this moment?"1

Samantha decided to write a letter to penetrate that darkness, addressed it to Andropov, and received a reply from the Kremlin inviting her to visit the Soviet Union and report what she saw. The most successful Soviet PR campaign of the late Cold War, the Smith visit demonstrated a creative, albeit short-lived, variation on the rich history of Soviet public relations. ${ }^{2}$ This surreal epistolary exchange and visit have attracted limited scholarly attention. ${ }^{3}$ And this article will add to the conversation by exploring some important but overlooked details in the context of evolving political narratives emerging out of Moscow and Washington in the early 1980s - the clash between the Soviet quest for legitimacy founded

1 Roger Rosenblatt, "Half a World Lies Open, Leonid Brezhnev Leaves a Vacuum Greater than the Man Who Filled It," Time, 22 November 1983, 11.

2 David Caute, The Dancer Defects: The Struggle for Cultural Supremacy During the Cold War (Oxford: Oxford University Press, 2003); Michael David-Fox, Showcasing the Great Experiment: Cultural Diplomacy and Western Visitors to Soviet Russia, 19211941 (New York: Oxford University Press, 2011).

3 Andreï Kozovoï, "L'enfance au service de la guerre froide: Le voyage de Samantha Smith en URSS (juillet 1983)," Vingtième Siècle. Revue d'histoire, No. 96 (Oct-Dec, 2007), 195-207; Margaret Peacock, "Samantha Smith in the Land of the Bolsheviks: Peace and the Politics of Childhood in the Late Cold War," Diplomatic History, Vol. 43, No. 3 (2019), 418-44; Matthias Neumann, "Children Diplomacy During the Late Cold War: Samantha Smith's Visit of the 'Evil Empire'," History (April 2019), Vol. 104 Issue 360, 275-308. 
on the Second World War foundation myth and the Reagan administration's remoralization of the Cold War with a renewed emphasis on American messianic exceptionalism. By then, the Soviet Union had squandered the sympathy of European leftists, while the conservative duumvirate of Ronald Reagan and Margaret Thatcher openly challenged the foundations of the Soviet way of life. Gone was the messianic spirit in Soviet propaganda - neither Brezhnev, nor his two immediate successors dreamed or threatened to outperform the West.

Yuri Andropov's recourse to cultural and public diplomacy therefore constituted an attempt to reinvent the Soviet regime's international image without reforming its fundamental structure, which would fall to Gorbachev. With its ideological magnetism spent, the only form of internationalism left to the Soviet leadership was to play on fears of a nuclear holocaust, which were very real by the early 1980s. By inviting the Smith family to tour the Soviet Union, Andropov made a last-ditch effort at a popularly driven, grass-roots détente that aimed to outmaneuver the Reagan government by appealing directly to the American people. However, this attempt to decouple geopolitical aspirations from domestic policies rendered Andropov's public relations gamble highly vulnerable. By the late twentieth century, Muscovy, the Romanov Empire, and Soviet Russia had developed a long tradition of cultivating and altering, imitating and rejecting, engaging and distancing, borrowing and quarantining Western models in all spheres of life. Andropov's attempt combined and reinvigorated these opposing tendencies in a PR tactic of unprecedented proportions channeled through the US but aimed at the entire world.

\section{Epistolary Overtures}

Having looked through the Time article, Samantha Smith asked her mother to write a letter to the General Secretary "to find out who was causing all the trouble." Instead, Jane Smith suggested that Samantha do it herself. And so she did. The hand-written letter read:

Dear Mr. Andropov,

My name is Samantha Smith. I am ten years old. Congratulations on your new job. I have been worrying about Russia and the United States getting into a nuclear war. Are you going to vote to have a war or not? If you aren't please tell me how you are going to help to not have a war. This question you do not have to answer, but I would like to know why you want to conquer the world or at least our country. God made the world for us to live together in peace and not to fight.

Sincerely,

Samantha $\mathrm{Smith}^{4}$

4 Samantha Smith, Journey to the Soviet Union (Boston: Little, Brown, and Company, 1985), 4 . 
Samantha's father Arthur Smith, a professor of English Literature at the University of Maine at Augusta, helped his daughter attach a 40-cent stamp to the letter and mail it to "Mr. Yuri Andropov, The Kremlin, Moscow, USSR."

A few months later on 11 April 1983, Pravda reprinted the letter and its facsimile along with quotes from other letters sent from the United States. The anonymous Pravda article about Samantha argued that the letters of ordinary Americans proved just how out of touch with its own population the Reagan administration had become in its aggressive narrative about the USSR. Introducing Samantha's letter, Pravda expressed surprise at the gross scale of disinformation to which "the dirty work of the military-industrial complex propagandists" had exposed the American public. "We think that Samantha can be forgiven for her confusion - she is only ten years old," the article concluded emphasizing the difference between the American people's views and wishes and their government's policies. $^{5}$

Since the Pravda article did not answer her questions, Samantha dashed off another epistle to Soviet ambassador Anatoly Dobrynin asking whether Mr. Andropov would ever respond. Samantha recollected: "About a week later I had a phone call from a man with a heavy accent. The caller said that he was from the Soviet Union, and he said that I would soon be getting a letter from Yuri Andropov. The man on the phone sounded like someone in a movie. I thought maybe this was one of Dad's friends playing a joke. He wanted me to call back when the letter came, and he gave me a bunch of telephone numbers to write down." Arthur Smith checked the numbers with the FBI and found out that the call came from the Soviet Embassy in Washington, DC. On April 25, a reply with Yuri Andropov's signature finally arrived.

Andropov's letter reminded Samantha that in World War Two, the USSR was "in alliance with the United States" and "fought for the liberation of many people from the Nazi invaders." Moreover, he stressed that the USSR "want very much to live in peace, to trade and cooperate with all out neighbors on this earth [...]. And certainly with such a great country as the United States of America." Andropov was invoking the second of two Soviet foundation myths - victory in the Second World War.

By definition an imperial myth that emphasized spheres of influence, state sovereignty, competitive coexistence, and international legitimacy, this myth was fundamentally defensive, unlike the first foundation myth that revolved around the October Revolution with its utopian, messianic, and Comintern-driven aim to spread revolution to the entire planet. Western confusion of the two myths found its most elucidating expression in two conflicting interpretations of post-war Soviet policies — George Kennan's "Long Telegram," which mistook the brutality of Soviet policies in Eastern Europe for revolutionary expansionism and Churchill's "Iron Curtain" speech several weeks later, which correctly recognized the creation

5 "Trevoga, nadezhdy, pozhelaniia, Iz-za okeana prodolzhaiut postupat pisma na imia Iu. V. Andropova," Pravda, 11 April 1983, 4.

6 Samantha Smith, Journey to the Soviet Union (Boston: Little, Brown, and Company, 1985), 8 . 
of a defensive sphere of influence. Although Khrushchev's embrace of decolonization marked a temporary embrace of revolutionary utopianism, Andropov was continuing Brezhnev's legitimacy-seeking mode. ${ }^{7}$

The General Secretary compared Samantha's courage and honesty to that of Becky Thatcher from Mark Twain's Adventures of Tom Sawyer, a novel "well known and loved in our country by all boys and girls." Samantha felt flattered by the comparison and took it as proof that "Mr. Andropov is not as grim a man as she had imagined." "When you think of Yuri Andropov," she told a reporter, "you really don't think about him having any humor." In answer to Samantha's question about Soviet war plans, Andropov's letter read: "We want peace-there is something that we are occupied with: growing wheat, building and inventing, writing books, and flying into space. We want peace for ourselves and for all peoples of the planet. For our children and for you, Samantha. I invite you, if your parents will let you, to come to our country, the best time being the summer. You will find out about our country, meet with your contemporaries, visit an international children's camp - 'Artek' — on the sea. And see for yourself: in the Soviet Union - everyone is for peace and friendship among peoples."

The children's weekly Pionerskaia pravda published Andropov's reply and quoted Samantha's father as saying that it was "warm, friendly, direct, and sincere." 10 The Soviet Embassy in Washington made the reply public, while the Toronto Star "offered to fly Samantha and her parents to Moscow for the visit." Andropov's gamble promised to pay off handsomely. The domestic and international environment of the time may explain the General Secretary's unexpected and friendly reply.

\section{The Cold War Background}

Andropov remains the most inscrutable of the Soviet leaders and only two biographies have explored the man who presided over the KGB for fifteen years before becoming General Secretary. ${ }^{12}$ After Khrushchev's de-Stalinization campaign, which institutionally demoted the security services from CommissariatMinistry to (the newly renamed) Committee, it fell to Andropov to bring the Soviet security apparatus to the apex of its size and efficiency by the early 1980s. As head of the KGB, which was the best informed about the depth of the coun-

\footnotetext{
7 For an in-depth discussion of the changing narrative towards the US, see Rosa Magnusdottir, Enemy Number One: The United States of America in Soviet Ideology and Propaganda, 1945-1959 (Oxford: Oxford University Press, 2019).

8 Peter Jackson, "It's a Red-Letter Day for Maine Girl," The Buffalo News, 26 April 1983.

9 Samantha Smith, Journey to the Soviet Union (Boston: Little, Brown, and Company, 1985), 6-9.

10 “Otvet Iu. V. Andropova na pismo amerikanskoi shkolnitsy," Pionerskaia pravda, 29 April 1983, 1.

${ }^{11}$ Peter Jackson, "It's a Red-Letter Day for Maine Girl," The Buffalo News, 26 April 1983

${ }_{12}$ Zhores Medvedev, Andropov (New York: Penguin Books, 1984); Leonid Mlechin, Andropov (Moscow: Prospekt, 2006).
} 
try's weaknesses and problems, Andropov brought to the Kremlin a desire for reform, albeit with a disciplinarian streak. His preference for the shadowy halls of power and reluctance to appear before television cameras contrasted greatly with Reagan's “great communicator” image of relaxed California-style openness. However, Andropov's speeches were brief and lacked the mind-numbing Party jargon that had become the norm during the late Brezhnev years. And despite his personal distaste for public appearances and fanfare, his government became more aware than Brezhnev's of the value of public relations, as the Samantha gamble demonstrated.

Conscious of the Soviet Union's economic backwardness and social apathy, Andropov first targeted corruption by dismissing hundreds of entrenched regional party bosses and bringing to Moscow young and ambitious talent from the provinces-Mikhail Gorbachev became his most famous protégé. After eighteen years of Leonid Brezhnev's rule, Soviet society had reached the apex of material comfort as well as popular apathy and ridicule of official propaganda. Many Soviet citizens had already withdrawn into their private lives to escape the officialese that saturated the Soviet media and public performances of defensive fealty, such as the annual "Zarnitsa" and "Orlyonok" wargames for Soviet youth at young pioneer camps. A few weeks before Artek switched over to peace mode for the Smith family, Soviet television showed young pioneers dressed in combat uniforms of Soviet border troops complete with model AK-47s and two-way radios romping around the woods and along the Black Sea coast "in a mock hunt for border violators." 13

The foreign policy front looked bleak. The Soviet was bogged down in Afghanistan and arms limitations talks had stalled, leaving Europe full of SS-20s and Pershing-2 "Eurorockets" and under the pall of potential nuclear Armageddon. The Campaign for Nuclear Disarmament was gaining strength in the US and Europe. Most importantly, in his attempt to overcome the "Vietnam syndrome" and pull the US out of its stagflation-induced torpor, Ronald Reagan's political rhetoric re-moralized the Cold War. Andropov's April invitation to the Smiths to visit the Soviet Union aimed to dispel the effect of Reagan's speech to the National Association of Evangelicals in Orlando, Florida, on March 8, 1983, in which he referred to the "aggressive impulses of an evil empire." Two weeks later, Reagan proposed the Strategic Defense "Star Wars" Initiative. Resurrecting the image of the US as a City on a Hill, Reagan also clearly communicated that the US did not recognize Soviet communism as a legitimate regime, that the new policy in Washington was to win, not to outlast the USSR, and that "peace" from his perspective was not a process of coexistence, but the result of a Western victory in the Cold War. Dormant for almost two decades since Eisenhower presided over the institutionalization of the Cold War, American exceptionalist messianism came roaring back with pride in the form of Reagan's optimistic conservatism. ${ }^{14}$ This view was

${ }^{13}$ Robert Gillette, "When Soviet Children Play War Games, It's for Real," Los Angeles Times, 23 July 1983, A1.

${ }^{14}$ Anton Fedyashin, "How Lenin and Wilson Changed the World," nationalinterest. org, 25 March 2017, https://nationalinterest.org/feature/how-lenin-wilson-changed-the- 
fundamentally opposed to Andropov's defensive geopolitical vision of the Cold War order, and he needed a PR coup to break the standoff, for which Samantha's letter provided a unique opportunity.

\section{Initial Reactions}

Within days of receiving Andropov's reply, international media laid siege to the Smith household. Pravda's New York correspondent Tomas Kolesnichenko barely got through to the household by phone. "This letter has turned my impression of the Soviet Union upside down," Samantha told him. "I believe every line in it. It is such a warm letter that it feels as if my father is talking to me. Now I am convinced that the Soviet Union is not planning to attack anyone." Kolesnichenko reported that Andropov's letter had also communicated to "millions" of Samantha's peers that the Soviet Union had peaceful aims, which the Reagan administration's propaganda machine had tried to distort. ${ }^{15}$

A few days before dashing off his letter to Samantha, Andropov had already replied publicly to a telegram from prominent American scientists - Carl Sagan among them-who opposed the militarization of space and the targeting of one another's satellites. "I can assure you that the Soviet Union will continue to exert maximum effort to prevent the ominous plans of transferring the arms race into space," Andropov stated. ${ }^{16}$ The reply to Samantha was therefore part of the Kremlin's wider public diplomacy strategy. The US Embassy in Moscow identified the "apparently deliberate softening of high-level Soviet rhetoric toward the United States" that received "heavy play in the Soviet central media."17

Every major US newspaper carried the story, but reactions differed. An article in the New York Times argued that Andropov's letter was part of a "broader effort" to persuade Americans of the USSR's good will and "to undercut public support... for the Reagan administration's plan to strengthen American nuclear forces." 18 Samantha remembered, "The reporters kept asking if I was nervous about all this, which I wasn't, but I wondered if I was supposed to be nervous." 19

world-19900 (last accessed 28 January 2020); Anton Fedyashin, "American Messianism and Russian-American Relations," in Russia and the United States in the Evolving World Order, eds. Anatoly Torkunov, Norma C. Noonan, Tatiana Shakleina, (Moscow: MGIMO University, 2018), 343-382; Arthur Herman, 1917: Lenin, Wilson, and the Birth of the New World Disorder (New York: Harper, 2017); David Foglesong, The American Mission and the "Evil Empire": The Crusade for a "Free Russia" Since 1881 (Cambridge, UK: Cambridge University Press, 2007).

15 T. Kolesnichenko, "Slovo pravdy, Schastlivyy den v zhizni Samanty Smit," Pravda, 27 April 1983, 4.

16 "Soviet Appeals to U.S. Scientists on Space Arms," Los Angeles Times, 27 Apr 1983, A2.

17 "SAMANTHA SMITH AND HIGH LEVEL SOVIET RHETORIC," Cable sent from US Embassy, Moscow, 27 April 1983, ID \#142046, WHORM: Samantha Smith, Ronald Reagan Library.

${ }^{18}$ John F. Burns "Andropov Assures Girl That His Nation Seeks Peace," New York Times, 26 Apr 1983, A10.

${ }^{19}$ Samantha Smith, Journey to the Soviet Union (Boston: Little, Brown, and Company, 1985), 9. 
After a while, the media circus became boring for her: "Everybody asks the same questions again and again. Why don't they just pass things along to each other?"20

In April 1983, Pionerskaia pravda began to publish letters from Soviet schoolchildren who had read Andropov's reply. Oksana Pototskaia of Osh in Kyrgyzstan believed that Andropov's letter addressed all the children of the world, so that everyone knew that the Soviet Union was "the greatest friend of all the children of the world." She added that her class visited Second World War veterans too old to participate in Victory Day celebrations in order to cheer them up "with bugles and drums"- which the veterans greatly appreciated, she believed - and called for American adults to "make friends" with their own children in order to prevent war. Vasia Slonov (seventh grade) of Shushinskoe village in Krasnoiarsk Region addressed Samantha in his letter and recounted how his school organized "labor landings" (trudovye desanty) at the local collective farm. After visiting Artek, Vasia argued, Samantha should come and help, too. Dima Ivanov of Leningrad described the crying women of Piskarev Cemetery where the victims of the Leningrad blockade were buried. "If you could only see this for yourself, you would immediately understand that our people do not want a war." ${ }^{21}$ Indeed, Samantha would visit the cemetery during her trip and called it "the saddest place on earth." 22

In Augusta, Samantha met Governor Joseph Brennan (D, 1979-1987) and spoke briefly before the state legislature. Some Americans suggested turning Samantha into a positive-PR campaign for the US by sending her to the Soviet Union as "the dove of peace" accompanied by the President and First Lady, several reporters, and "a very limited number of government officials and politicians," such as "Tip O’Neall, Howard Baker, and Mrs. Kirkpatrick." 23

By May 1983, an avalanche of letters from concerned Americans flooded the Kremlin, reported the Communist Youth Organization newspaper Komsomolskaia pravda, although some also complained about being misquoted. Samantha's letter also inspired Soviet citizens to write directly to Yuri Andropov. The US press reported on a letter from fifth-grader Irina Tarnopolsky of the Ukrainian city of Kharkov who was inspired by watching interviews with Samantha Smith on Soviet television. Irina asked why her refusenik father was being held incommunicado for four months after being arrested for "slandering the Soviet system," which carried a three-year sentence in a labor colony or internal exile. ${ }^{24}$ The US embassy in Moscow informed USIA in June 1983 that the American correspondent who originally translated Irina's letter and wrote an article about it "had his office searched in his absence and all three copies of the letter which he had stored there removed. The

${ }^{20}$ Geoff Williams, "The Littlelest Diplomat," Entertainment Weekly Magazine, 26 April 1996.

21 “Priezzhai v 'Aterk', Samanta!” Pionerskaia pravda, 1 May 1983, [2].

${ }^{22}$ I. Afanasiev, "'Nash dialog prineset liudiam polzu"” Pionerskaia pravda, 22 July 1983, [3].

${ }_{23}$ Telegram, Mr. and Mrs. Donald K. Jelks to President Ronald Reagan, 26 April 1983, ID \#142046, WHORM: Samantha Smith, Ronald Reagan Library.

${ }^{24}$ Robert Gillette, "Unlike American Child, Irina Fails to Move Yuri," Los Angeles Times, 13 June 1983, B1. 
entire file on the Tarnopolsky case was also mysteriously removed from the offices of another American news agency in Moscow." 25 Andropov's former employees were carefully managing the PR-campaign behind the scenes.

Declassified State Department documents show that in late April, Arthur Smith phoned the European and Soviet Desk "to ask for the State Department's views on the trip." State answered that it "considered this to be [the family's] decision and that if they decided to go, the Department would assist however possible" both in the US and in Moscow. State warned Smith, however, that "the Soviets are using and would continue to use the invitation for political and propaganda purposes." Smith responded that "he realized the Soviets had their own motives" and that he did not want his daughter's visit to turn out like Billy Graham's because she was "not as naïve." The Smiths clearly did not subscribe to born-again conservative politics. The declassified State Department summary of the phone conversation quoted Smith as saying that he wanted the trip "to be a low profile, educational experience for Samantha, not a press circus" and he accepted State's offer of a briefing prior to the trip. ${ }^{26}$

The State Department also decided to use the Smith trip to pressure the Soviet government into allowing families with children to reunite. Foggy Bottom sent Tom Simons to Maine in late June to brief the family and present it with a "children's representation list" that the Smiths would hand to the Soviets. "A preliminary check indicates," read an internal memorandum, "there are six families with children under 18 who are separated from close relatives because they cannot get exit permission." 27

Jewish emigration from the Soviet Union declined from its apex of over 50,000 in 1979 to fewer than 3,000 by 1982. Irina Tarnopolsky never received a reply to her letter and her father received the maximum sentence after refusing to answer the court's questions. ${ }^{28}$ Letters from Soviet émigrés petitioning the Soviet government to grant exit visas to their relatives also flooded the Smith household, which they brought to Moscow. Meanwhile, the Soviet press had a field day when a Soviet girl's letter addressed to Ronald Reagan at the White House was returned. The address had been written in Cyrillic, transliterated into English by someone at USPS, and still sent back marked "Addressee unknown." 29

American kids also picked up their pens to ask questions of President Reagan. Some of these letters were routed through the National Security Council and the State Department, which weighed in on the answers. Ms. Holly Nachbar of Springville, New York, wrote to the White House that as she read an article about Andropov's reply to Samantha in The Buffalo News, "at first I believed him and

25 "Subject: Letter from Irina Tarnopolsky to Andropov," U.S. Department of State, Case No. F-2011-25766, Doc No. C05104822.

${ }^{26}$ U.S. Department of State, Case No. F-2011-25766, Doc No. C05104830.

27 “Andropov's Pen-Pal Samantha Smith," U.S. Department of State, Case No. F-2011-25766, Doc No. C05104824.

${ }^{28}$ Robert Gillette, "Soviet Scientist Sentenced to 3 Years in Labor Camp," Los Angeles Times, 1 July 1983, SD6.

29 "Soviet girl's note to Reagan returned, address unknown," Chicago Tribune, 17 June 1983. 
thought him to be an honest man, but I urge all who read it, study it and read deeper than the words on the paper." "Does he really want peace," Holly asked President Reagan, "or is he playing dirty-pool?" She signed her letter "Truly an American." 30

The stream of letters from Soviet children to Pionerskaia pravda continued into the summer of 1983. According to the editors, the common denominator among them was the opinion that Andropov spoke for all Soviet children. Sveta Kuprina from Georgievka village in Kuibyshev Region wrote that the Soviet people did everything possible to ensure that its children live under "a blue sky and that when seen from space the earth resemble a blue sphere, not a black cloud." ${ }^{31}$ Many kids wrote in about their grandparents' losses during the Second World War as proof that the Soviet Union did not want another conflict. In June 1983, members of Moscow's Club of International Friendship (Klub internatsionalnoi druzhby imeni Iuriia Gagarina or KID) sent a letter to their American counterparts, the content of which they recorded in a telephone message that was played at a meeting in San Francisco during the International Day for the Protection of Children. Pionerskai pravda carried the story on its front page. ${ }^{32}$

Youth activism and the role and uses of childhood during the Cold War have received commendable treatment from scholars. ${ }^{33}$ It is worth adding here that the youth activism that Samantha unleashed stood in stark contrast to the commodification of youth culture during the early 1980s — a trend that the Western "victory" in the Cold War would successfully export to the rest of the world. The Reaganera consumer revolution would hijack the activist youth counterculture of the 1960s and 1970s and transform it into an addiction to excess and financial debt. In a strange parallel to the late Soviet phenomenon, the emergence of America's young people as both market rulers and its targets, morphed activism into consumer solipsism - personal spending as fulfillment, the "Valley Girl" phenomenon, consumer fantasies, and celebrity cults. Samantha Smith was a sobering but temporary pause in this trend.

\section{Moscow}

The Smiths left first-class on their all-expenses-paid two-week trip on July 7 , 1983. According to Jane Smith, the State Department prepped the family for the

${ }^{30}$ Letter, Holly Nachbar to President Ronald Reagan, 26 April 1983, ID \#148936, ND018, WHORM: Subject File Ronald Reagan Library.

31 "Pisma dlia Samanty," Pionerskaia pravda, 24 May 1983, [2].

32 "Dialog cherez okean vedut sovetskie pionery s detmi Ameriki," Pionerskaia prav$d a, 3$ June 1983, [1].

33 Jennifer Helgren, American Girls and Global Responsibility: A New Relation to the World during the Early Cold War (New Brunswick, NJ, 2017); Sara Fieldston, "Little Cold Warriors: Child Sponsorship and International Affairs," Diplomatic History 38, no. 2 (April 2014): 240-50; Susan E. Reid, "Destalinization and Taste, 1953-1963," Journal of Design History 10, no. 2 (January 1997): 177-201; Catriona Kelly, "Defending Children's Rights, 'In Defense of Peace': Children and Soviet Cultural Diplomacy," Kritika: Explorations in Russian and Eurasian History 9, no. 4 (Fall 2008): 711-46; Marina Balina and Evgeny Dobrenko, eds., Petrified Utopia: Happiness Soviet Style (New York, 2011); Margaret Peacock, Innocent Weapons: The Soviet and American Politics of Childhood in the Cold War (Chapel Hill, NC, 2014). 
trip "even though they didn't want to be seen as endorsing it." 34 The family flew from Augusta, Maine, to Boston, and then to Montreal. In Boston, Arthur Smith declared that if the family trip "would be turned into a propaganda advantage by either country," they would not have undertaken it. ${ }^{35}$ "Reporters in Montreal," Samantha recalled, "seemed to go wild and even the Royal Canadian Mounted Police, who were trying to guide us, had trouble holding back the people when the reporters started shoving. They were all pushing microphones at me and shouting and then we got all jammed up and I bit one of the microphones that was pushed up against my face." ${ }^{36}$

A similar throng of European, American, and Soviet journalists met the Smith family in Moscow's Sheremetyevo Airport. "I want to make friends with Soviet kids," Pravda quoted Samantha upon arrival, "I hope to make a close friend here, a fifth-grade girl." ${ }^{37}$ Young pioneers from Moscow's Palace of Youth met her at the airport with bouquets of flowers. ${ }^{38}$ Remembering their trip years later, Jane Smith admitted that she was most surprised by how well the Soviet government had organized their itinerary: "We were met with the highest diplomatic etiquette." ${ }^{39}$ This was her second visit to the USSR where she had already been in 1964 with her college class. Soviet television gave Samantha's arrival prime time coverage, abandoning the usual fare of interviews with workers and peasants. The Union of Soviet Societies for Friendship and Cultural Relations with Foreign Countries (USSFCRFC), which paid for the trip, put the Smiths up at Sovetskaia Hotel in the center of Moscow - an honor reserved for the highest echelon of visitors to the USSR. The family called on US ambassador Arthur Hartmann on the afternoon of July 8 and received his offer of "any assistance they might need in passing messages to the States," but had not heard back from them (until at least July 10). ${ }^{40}$ The family's attorney, Mr. George Haldeman, stayed in touch with the Smiths through the US embassy in facilitating "arrangements with the press."

The next morning, the Smiths toured Red Square and the Kremlin in a throng of journalists. Their picture appeared in Pravda. ${ }^{42}$ One of the places where they

\footnotetext{
${ }^{34}$ Josie Huang, "Remembering Samantha," Portland Press Herald, 13 July 2003.

35 "Yuri's U.S. pen pal takes off on expenses-paid Soviet trip," Chicago Tribune, 8 July 1983, 3 .

${ }^{36}$ Samantha Smith, Journey to the Soviet Union (Boston: Little, Brown, and Company, 1985), 17.

37 S. Demidov, "Dobro pozhalovat, Samanta!" Pravda, 9 July 1983, 4. 1983, 3 .

${ }^{38}$ E. Kaliadina, "“Pust Samanta podruzhitsia s nami!," Komsomolskaia pravda, 9 July

${ }_{39}$ Aleksei Anishchuk, "'Samolet snizilsia, mem'," Moskovskii komsomolets, 5 August 2004 .

40 “'Official Informal No. 135," U.S. Department of State, Case No. F-2011-25766, Doc No. C05105026.

41 "Samantha Smith: Our Office Received a Telephone," U.S. Department of State, Case No. F-2011-25766, Doc No. C05105035.

42 Pravda, 10 July 1983, 6. The caption read: "Guests from all over the world come to Moscow. In the pictures: school girl from the American state of Maine with her parents on Red Square." Another picture showed members of the XIII International Film Festival at the Kremlin.
} 
stopped was Yuri Gagarin's plaque in the Kremlin wall. In the office of Zinaida Kruglova, the Chairman of the USSFCRFC and a member of the CPSU Central Committee, Samantha received a call from Valentina Tereshkova, the first woman astronaut, who invited her to tea. One thing that the Soviet press did not show, but the American press picked up, of course, was the breakdown of the Chaika limousine that the Soviet government provided for the Smiths, which had to be replaced with a blue-and-yellow Mercedes-Benz sedan belonging to the Soviet militia.

\section{The Crimea}

The next day, a group of young pioneers met the Smiths at Simferopol Airport in the Crimea and accompanied them to Artek. On the road, the Soviet kids asked Samantha about her favorite sport, which turned out to be softball. They asked her if she had read any Soviet literature. With her mother she had read the children's writer Kornei Chukovski. Asked about her grades, Samantha responded that everything was alright until the journalists laid siege to her house. "Samanthamania," as Jane Smith put it, had officially begun in the Soviet Union as the state channels reported daily on Samantha's itinerary. ${ }^{43}$

In an interview published in the 1990s, Olga Sakhatova, the English-speaking Artek camp counselor placed in charge of Samantha, said that the Artek administration gathered the counselors the day before for a "political information" session during which they were directed "not to get in the way of the cameras, not to converse with enemy journalists" and the camp director even quipped that if anyone strayed, he would institute rule by emergency decree and "everyone will live as if in a real camp." 44 According to Sakhatova, the day of Samantha's arrival, the head of Artek asked her a hundred times: "Sakhatova, be honest, do you actually understand English or not?!" "After a while, I started to doubt it myself," she remembered.

One press bus fell behind after leaving the airport and the second took a wrong turn on the way to the camp, so when the Smith family arrived at Artek, there were only the kids to meet them. Several minutes later, the press caught up and sprinted from the parking lot to the main quad where the initial welcoming ceremony had already ended. The camp administration became so nervous at the sight of the stampeding journalists that they hurried the Smiths into the Morskoi dormitory. ${ }^{45}$ The head of the camp asked Samantha whether she wanted to stay with her parents or with the kids and she chose the latter, so she joined Morskoi, which had Englishspeaking residents. Arthur Smith asked the head of the camp to keep the journalists away from Samantha. Natasha Kashirina became Samantha's bunk neighbor. The daughter of an English teacher from Leningrad, she had the strongest English at camp and a bunk was set up for Samantha right next to hers.

Samantha received a blue and white visitor's scarf which read: "Let there always be sunshine!" These were the opening lines of what became her favorite

\footnotetext{
${ }^{43}$ Dmitrii Bykov, irina Lukianova, "Tri goda Samanty,” 2000, http://www.artekovetc. ru/press6.html, accessed on 3 December 2008.

44 "V arteke Samantu Smit ispugali zheltye sosiski i bditelnost spetssluzhb," http:// rep-ua.com/20865.html, accessed on 3 December 2008.

45 "V arteke Samantu Smit ispugali zheltye sosiski i bditelnost spetssluzhb," http:// rep-ua.com/20865.html, accessed on 3 December 2008.
} 
song. She also donned the blue pioneer uniform complete with the pilotka, or aviator cap, which was reserved for visitors (the young pioneers, of course, wore the red). The Artek community immediately accepted Samantha and she exercised and ate with the Soviet children. In the Pioneer Palace, Samantha visited an exhibit covering the Soyuz-Apollo mission where she correctly identified a portrait of Gagarin. She also attended a meeting of the "International Political Club," which on that day happened to be discussing the Senate Arms Committee decision to vote an extra $\$ 186$ billion for "new missiles." Artek's pioneer headquarters (shtab) invited Samantha to their meeting in order to educate her about the organization. Andrei Babkin of Briansk told her that education was the young pioneers' most important activity, which enabled them to give back to society-he wanted to become an astronomer. Rita Podkovyrova had not made up her mind regarding her career path, but she was convinced that manual labor made people happy. Liuda Flutkova from Ashkhabad said that the Turkmens had been almost completely illiterate before the revolution, but now they had "scientists, a museum, and music schools." Samantha had no questions. ${ }^{46}$

Since she was a special guest, camp rules were relaxed for counselor Olga and Samantha's friend Natasha, and instead of taking the obligatory - and uncompromisingly imposed - mid-day nap, the girls played on the beach. Once while they were swimming, a lifeguard rowed over in a boat and took them for a ride, which was cut short by a motorboat with a dark-suited KGB agent who seemed to appear out of nowhere and shouted at the lifeguard and Olga for taking "such an important guest" on an "unsanctioned sea stroll without a life vest." There was no policy of life vests in Artek at the time. Olga calmed the frightened Samantha by telling her that being out in the sun for too long had made the man irritable. When a boy in a stained shirt attracted Samantha's attention during dinner in the mess hall, Olga explained that he was a young painter and would change after dinner. He later received an official reprimand for "incompatibility with Soviet ideals." Samantha also asked Olga why the sausages they ate were yellow in color and Olga explained that they were of a special variety, but Samantha refused to eat them anyway. As soon as the kitchen staff noticed the incident, one of the cooks appeared with a tray full of goods that were never on the menu. ${ }^{47}$

On Sunday July 10, the "Artek Republic" - ten sections made up the camporganized a children's postcard campaign, which targeted NATO headquarters in Brussels, the White House, the heads of "major capitalist countries." According to Artek tradition, a boat released the bottled messages into the sea. Samantha wrote on her card: "I am for peace in my lifetime! Samantha." In an article about Samantha's days in Artek, Komsomolskaia pravda concluded: "Children and peace - for us, Soviet children, there is nothing more valuable than this. Now you know this, Samantha!"48

${ }^{46}$ T. Krasnova, I. Afanasiev, and V. Mashatin, "Ia liubliu tebia, 'Atek'!” Pionerskaia pravda, 19 July 1983, [2].

47 "V arteke Samantu Smit ispugali zheltye sosiski i bditelnost spetssluzhb," http:// rep-ua.com/20865.html, accessed on 3 December 2008.

${ }^{48}$ E. Ovcharenko, E. Uspenskii, “'Za mir na vsiu zhizn! — napisala na otkrytke Sa- 
Samantha wrote, "Sometimes at night we talked about peace, but it didn't really seem necessary because none of them hated America, and none of them ever wanted war. Most of the kids had relatives or friends of their families die in World War II, and they hoped there would never be another war. It seemed strange even to talk about war when we all got along so well together." ${ }^{49}$ During a tour of the Yalta Palace, the head of the museum let Samantha climb into the chair where FDR had sat in 1945. The Second World War foundation myth emphasized the mutually respectful and beneficial war-time cooperation as a standard to which Moscow hoped to return. Samantha wrote in the Visitor's Book: "I have fallen very much in love with your camp and I would like to return. Your grown-ups and children - are the best on Earth. Peace to all!" Addressing the Artek kids before her departure during a bonfire ceremony, Samantha read a note that her father helped her to compose: "My visit to 'Artek' was very good. I think that we will remain friends even across the ocean. I love you, 'Artek'!" The pioneers gave her an ember of the bonfire as a keepsake. ${ }^{50}$ According to Sakhatova, film cameras from all over the world filmed the farewell ceremony, but only the Soviet cameraman ran out of film half way through, which is why the central news channel aired a shortened version of the event on the nightly news. ${ }^{51}$ Before leaving Simferopol, a local collective farm hosted the family to a sumptuous meal.

\section{Leningrad and Moscow}

From the Crimea, the Smith family travelled to Leningrad where they attended a performance of The Fountains of Bakhchisarai by the Kirov Ballet. Ballerina Alla Chizheva gave Samantha an autographed pair of toe shoes. A cable from the US consulate in Leningrad described "a cortege of Chaikas usually reserved for visits by heads of state" roaring up to the "House of Friendship" on July 14 and "as doors flew open and militia men stood at attention, little Samantha Smith got out and was escorted inside." The cable continued: "Aside from the melancholy which one feels at seeing the agit-prop machine exploit a small child, one must admit that this type of thing strikes a responsive chord in the hearts of most Russians." 52

"I liked everything in your country," Samantha told Izvestiia. "Your country is beautiful, but the main thing is the kindness and warmth of all the Soviet people_-both grown-ups and children." If she were a magician, she added, she would make "all the bombs disappear." When reporters asked her whether she wanted

manta Smit, kotoraia v eti dni stala gostiei 'Arteka'," Komsomolskaia pravda, 12 July 1983, 3 .

${ }^{49}$ Samantha Smith, Journey to the Soviet Union (Boston: Little, Brown, and Company, 1985), 49.

${ }^{50}$ E. Ovcharenko, E. Uspenskii, “"Vashi vzroslye i deti-luchshie na zemle!',” Komsomolskaia pravda, 14 July 1983, 3.

51 “O Samante, shokoladkakh, bandikakh i bditel'nykh spetssluzhbakh, Samanta Smit v Arteke-kak eto bylo na samom dele (vospominaniia ee vozhatoi)" http://www.artekovetc.ru/samsmitvoj.html, accessed on 3 December 2008.

52 "Samantha in Leningrad," U.S. Department of State Cable, Case No. F-201125766, Doc No. C05105024. 
to be an astronaut, Samantha replied that she preferred to become a veterinarian because she loved animals. ${ }^{53}$

Back in Moscow, Samantha had lunch at the American Ambassador's residence known as Spaso House. The day after, she met Tereshkova at the offices of the Soviet Women's Committee and visited the Exhibit of People's Economic Achievements (VDNKh), toured the Bolshoi (which was closed for repairs) and the Krylatskoe Olympic Center, and attended a show at the Moscow Circus. "The Soviets love kids so much that I might be spoiled if I lived here." "Mr. Andropov was still very busy with his government work," Samantha wrote in her book, and a personal meeting never happened. But the truth was that he was already sick with kidney failure. Instead, the head of the Central Committee's Department of Information, Leonid Zamiatin, met with Samantha and for the first time she caught a glimpse of the Soviet hierarchy: "Gennady did the translating between us, but I think Mr. Zamiatin knows English. A couple of times he interrupted Gennady's translation and changed the words. One of the waiters was serving Russian tea to everybody, and he was so nervous that the teacups rattled like crazy when he carried them to the table. I was staring at the waiter because it was funny, but I didn't laugh. I don't think he was nervous about me." ${ }^{55}$

At the last children's press conference in Moscow's Pioneer Palace, Samantha promised "to tell everyone at home what I had seen. And, most importantly, what I found out - that not a single Soviet person, neither old, nor young, wants war." ${ }^{56}$ Having augmented her Russian vocabulary during her stay, Samantha said goodbye at Sheremetyevo Airport with the words "Do svidaniia, dorogie druzia [Goodbye, dear friends]." ${ }^{57}$ However, when she was invited to put her name under a "vote for peace" that included a condemnation of plans for stationing new US missiles in Europe, Jane Smith intervened and the card remained unsigned. ${ }^{58}$

In the conclusion to her book, Journey to the Soviet Union (1985), Samantha summed up her trip: "The world seems not so complicated as it did when I looked at travel books from the library. And the people of the world seem more like people in my own neighborhood. I think they are more like me than I ever realized. I guess that's the most important change inside me." 59

\section{Reactions}

The Smiths returned to Montreal on July 22 to a Soviet Consulate limousine that drove them to their hotel. They turned down complimentary tickets to

\footnotetext{
${ }^{53}$ A. Valentei, "Esli b i byla volshebnitsei," Izvestiia, 17 July 1983, 2.

${ }^{54}$ Samantha Smith, Journey to the Soviet Union (Boston: Little, Brown, and Company, 1985), 110.

${ }_{55}$ Samantha Smith, Journey to the Soviet Union (Boston: Little, Brown, and Company, 1985), 115.

${ }_{56}$ I. Afanasiev, "Nash dialog prineset liudiam polzu"” Pionerskaia pravda, 22 July 1983, [3] and A. Valentei, "Do novykh vstrech, Samanta!" Izvestiia, 22 July 1983, 6.

57 "Samanta Smit: "Do vstrechi, druzia'," Komsomolskaia pravda, 22 July 1983, 3.

${ }^{58}$ John F. Burns, "It's Back to Maine for Schoolgirl Who Disarmed the Russians," New York Times, 22 July 1983, A2.

59 Samantha Smith, Journey to the Soviet Union (Boston: Little, Brown, and Company, 1985), 119.
} 
a baseball game that evening, however. As soon as the Smiths returned to the US — with between 14 and 24 pieces of luggage (by different accounts) and gifts packed neatly in red paper - their trip became a cause célèbre in the American press. Former US Ambassador to Moscow Malcolm Toon (1976-1979) attacked the public relations stunt as designed to make the Soviets look like promoters of peace with no responsibility for international tension. Toon saw Moscow as successfully "exploiting" Samantha Smith with "the possible result that we could end up in a confrontation that nobody wants." ${ }^{\circ 0}$ Sitting Ambassador Arthur Hartman (1981-1987), however, called the visit "a plus to us all." $" 61$

Asked whether what they had seen the real conditions in the Soviet Union, the Smith family answered diplomatically that when someone invites you to their home, they do not show you its worst rooms - Samantha walked away from her trip with an impression that there were "good and bad people in both countries," but that the Soviet people were not aggressive. According to Jane Smith, they were aware that the "KGB and CIA closely monitored their visit" and that Samantha's name became a propaganda tool, but "propaganda of kindness and peace is not that bad of a thing." ${ }^{62}$ Arthur Smith maintained that Soviet officials "were careful to avoid propaganda" and "let the kids be kids with one another."

Some Americans wrote letters to newspapers claiming to be revolted by the whitewashing of the Soviet Union and the Smiths' naiveté. A reader of the LA Times brought up Irina Tarnopolsky's father who was serving a three-year sentence in a labor camp outside of Chita near the Manchurian border. The girl's plea "along with thousands of others, was treated like dirt and swept under the Red carpet." ${ }^{64}$ While the fate of the refuseniks came up in dozens of published letters, other struck a more moderate tone. "And yet, who are we to throw stones?" wrote a resident of Illinois. "“Do we, when foreign dignitaries visit, show them our Indian reservations, our ghettoes or our lines of the unemployed? ... We all play the same old game: You pretend to fall for our snow job and we pretend to fall for yours." 65 "Ninety-nine percent of the letters urged her to go," said Samantha's grandmother about the mountain of mail to which the Smiths returned at their house. ${ }^{66}$ Even President Ronald Reagan appealed to childhood wisdom when he opened a press conference on US policy in Central America with a quote from a letter he had received from thirteen year old Gretchen. "Don't you wish sometimes you could just stamp your feet and shout at the press or senators to be quiet, and sit down and listen to what you're saying?"67

${ }^{60}$ Chuck Conconi, "Personalities," Washington Post, 13 July 1983, D3.

61 "Headliners," New York Times, 17 July 1983, E8.

${ }^{62}$ Aleksei Anishchuk, "'Samolet snizilsia, mem'," Moskovskii komsomolets, $5 \mathrm{Au}-$ gust 2004 .

63 "Samantha returns, says Soviets don't want war," Chicago Tribune, 22 July 1983, 3.

${ }^{64}$ Lillian Goldman, "Samantha Smith's Visit to Russia," Los Angeles Times, 25 July 1983, C4.

${ }^{65}$ Eva Baker Watson, “A Soviet snow job,” Chicago Tribune, 23 July 1983, 8.

66 "From Russia Back to 'Regular Things'," New York Times, 23 July 1983, 5.

${ }^{67}$ Mary McGrory, "Central America Policy Is a Problem Only for Close Listeners," Washington Post, 28 July 1983, A3. 
The White House received letters directly from American citizens or through their Representatives. Morton Matthew of Connecticut asked Reagan to return Andropov's invitation and to open a "hairline crack in the iron-uranium wall between east and west" by inviting a Russian girl to visit the US. Urging a direct dialogue between ordinary citizens, Matthew wrote, "Samantha might be the start of something tremendous." ${ }^{68}$ The White House responded that it avoided "highly visible and well-publicized visits" that "gave a misleading impression about Soviet policies." Since the Soviet Union continued to disregard "understandings embodied in the Helsinki Final Act," including free travel and access to information for its citizens, highly publicized trips such as the Smiths' was simply a way around the Helsinki Accords and the Reagan administration would not fall for this Soviet ploy. ${ }^{69}$

Back in Maine, Samanthamania now infected the US. During a press conference at their home, Arthur Smith said that Samantha "would keep her comments to a minimum until he lines up a schedule of television appearances." ${ }^{\prime 70}$ During the homecoming parade, Maine Governor Joseph Brennan praised Samantha "for conducting her visit to the Soviet Union with grace, with charm and with a simple but elegant message of peace." "'1 The US media aggressively pursued the new Cold War celebrity. CBS and NBC sent a chartered plane to Maine to retrieve Samantha and her mother for appearances on the CBS Morning News, the Today Show, and Nightline. Ted Koppel, Jane Pauley, and Diane Sawyer interviewed her. She was flown to California to meet Johnny Carson and appear on his show. The Smith family hired lawyer George Haldeman to act as Samantha's agent.

When a member of the audience during the Phil Donahue Show mentioned that the Smiths' trip was "the greatest propaganda stunt the Soviets could hope for," Arthur Smith responded that the real value was to introduce the Soviet people to "the independent spirit of the American child." Samantha appeared on the Phil Donahue Show together with a seventeen-year-old Presidential Scholar who presented President Reagan with "a controversial nuclear arms freeze petition" after accepting her medallion at the White House..$^{72}$ The harshest criticism of the Samantha Smith phenomenon came from columnist Charles Krauthammer. "To gloss over contradictory interests, incompatible ideologies and opposing cultures as sources of conflict is more than antipolitical," he wrote equating the Soviets with the Iranians and Syrians. "It is dangerous. Those who have long held a mirror to the world and seen only themselves are apt to be shocked and panicked when the mirror is removed, as inevitably it must be." ${ }^{.73}$

${ }^{68}$ Letter, Morton P. Matthew to Hon. Nancy L. Johnson, 11 July 1983, ID \#154386, C0165, WHORM: Encloses Letter from Mr. Morton R. Matthew, Writes Concerning Samantha Smith, Ronald Reagan Library.

${ }^{69}$ Letter, Alvin Paul Drischler to Hon. Nancy L. Johnson, 8 September 1983, ID \#154386, C0165, WHORM: Encloses Letter from Mr. Morton R. Matthew, Writes Concerning Samantha Smith, Ronald Reagan Library

70 "Samantha's hometown gives a parade welcome," The Sun, 24 July 1983, A7.

71 "Girl Welcomed Back From U.S.S.R.," New York Times, 24 July 1983, A2.

72 Joseph Sjostrom, "Samantha appears on Donahue show, charms audience," Chicago Tribune, 16 August 1983, A13.

${ }^{73}$ Charles Krauthammer, "Essay: Deep Down, We're All Alike, Right? Wrong," Time Magazine, 15 August 1983. http://www.time.com/time/magazine/article/0,9171,949728,00. html last accessed 4 February 2011. 


\section{KAL 007}

The Smith trip's PR success proved short-lived when Soviet interceptors shot down Korean Air Lines flight 007 just west of Sakhalin Island on 1 September 1983. All 269 people onboard died. And instead of admitting and explaining the unintended tragedy, the Soviet government decimated its credibility by stonewalling. The Reagan administration and Western media pounced on the issue obliterating the remains of whatever good will the Smith visit had generated a month and a half earlier. According to Seymour Hersh, before going public about the tragedy Reagan had signed a National Security Decision Directive stating that it presented "an opportunity to reverse the false moral and political 'peacemaker' perception that [the Soviet] regime had been cultivating." "I4 In response to this, the Soviet delegation walked out of nuclear arms reduction talks in Geneva.

Although the National Security Agency informed the White House that according to their decrypts, the Soviets genuinely believed that they were tracking an American RC-135 reconnaissance aircraft instead of a Boeing passenger jet, the Reagan administration ignored the intelligence. ${ }^{75}$ In response to a letter from a young man from Santa Fe who inquired whether the White House intended to follow up on the Smith visit to the Soviet Union, the administration responded that as a "hostile, predatory empire," the USSR had demonstrated its ruthlessness many times_-"a few weeks ago the murderous attack on an unarmed civilian airliner with 269 passengers aboard was a chilling reminder of Soviet contempt for human life." 76

The incident reflected directly on the Smith family's hope to lessen Cold War tensions and the blowback implicated them. A reader of the Chicago Tribune ridiculed Samantha's statement about the USSR's peaceful intentions: "It would be interesting to hear her comments now." 77 Another letter accused the Smiths of doing "Moscow's bidding." 78 Some readers, however, were disgusted at the "grim and thoughtless undercurrent of satisfaction" in the Soviets' losing a PR move. ${ }^{79}$ "We are not Soviet experts even after two weeks there," AP quoted Arthur Smith. "But this incident is the best example you could find to continue to find solutions to international problems." 80

\section{Stardom}

In December 1983, Samantha attended an International Children's Symposium in Kobe, Japan, at the invitation of a trade group promoting Japan's science and technology exposition Tsukube ' 85 . Her newfound popularity in Japan made her a valuable brand. In Kobe, Samantha proposed that Soviet and American lead-

${ }^{74}$ Anthony Lewis, "Why Reagan Blinked," New York Times, 2 October 1986, A23.

${ }^{75}$ Matthew M. Aid, The Secret Sentry: The Untold Story of the National Security Agency (Bloomsbury Press: New York, 2010), 174-175.

${ }^{76}$ Letter, Ronald Reagan to Mr. Dale A. Garcia, 1 November 1983, ID \#183454, C0165, WHORM: Samantha Smith, Ronald Reagan Library.

${ }_{77}$ David A. Heckler, Letter to the Editor, Chicago Tribune, 10 September 1983, 8.

${ }^{78}$ David Wilkie, Letter to the Editor, Chicago Tribune, 11 September 1983, C2.

${ }^{79}$ Ellen Goodman, “A Hollow Victory,” The Sun, 16 September 1983, A15.

80 "Samantha Smith 'upset' by airliner incident," The Sun, 7 September 1983, B3. 
ers exchange granddaughters for two weeks every year, arguing that leaders would not want to bomb countries that their granddaughters were visiting. Samantha brought a copy of Nicholas Meyer's recently released apocalyptic film The Day After and then traveled to Tokyo to meet Japanese Prime Minister Yasuhiro Nakasone. "If she doesn't get an agent," a Washington Post columnist quipped, "she'll probably next be invited to a plumbing and hardware manufacturers exposition in Zagreb." 81 Asked where she would like to go next, Samantha said "Ireland." The Washington Post reported acidly that there was neither indication of a letter to Prime Minister Garrett Fitzgerald, "nor mention of a telegram to Sinn Fein." 82

Samantha then went on to host a children's special for the Disney Channel entitled "Samantha Smith Goes To Washington... Campaign '84," for which she interviewed several presidential candidates, including George McGovern and Jesse Jackson. By the time "pigtail diplomacy" yielded to "pigtail journalism," she was travelling with a media agent and Arthur Smith took leave from his teaching job to handle her career. ${ }^{83}$ Samantha's life now adopted the tell-tale signs of $1980 \mathrm{~s}$ stardom as she began to morph from peace activist to peace celebrity. But then pop icon status was necessary for political influence in the 1980s, the decade of brands, when America's most successful brand, Ronald Reagan, had himself been a film star. Margaret Peacock correctly noted that while the Soviets saw childhood as a stage of communist character formation, Reaganite conservatives dismissed it as a period of dangerous "fables and fanciful dreams" about coexistence and world peace to be cured by experience and moral clarity. ${ }^{84}$ The American entertainment industry, however, treated childhood as a marketing opportunity as America's youth was fast evolving into the MTV generation with enormous commercial clout — ready to consume and be manipulated into consuming.

Ironically, the Wall Street Journal gave credit to "Cecil B. Andropov" for turning "an American pre-teen into a bona fide celebrity" as only "a theatrical producer" can. ${ }^{85}$ In The New Republic, Krauthammer complained that adults used to ask kids' opinions about the world "in order to find out about kids; now we do it to find out about ourselves." 86 Confronted by Arthur Smith in the magazine's office, Krauthammer responded that "there was a good reason the voting age was 18 and not 12." ${ }^{\circ 7}$ All jokes aside, however, when the Washington elite-George Schulz, Henry Kissinger, George F. Kennan, Clark Clifford, Anatoly Dobrynin, and many others - gathered to celebrate Dean Rusk's $75^{\text {th }}$ birthday in February 1984 at the State Department, Samantha Smith was on hand to present the birthday cake together with Rusk's two granddaughters.

${ }^{81}$ Chuck Conconi, "Personalities," Washington Post, 23 December 1983, D3.

82 "Personalities," Washington Post, 2 January 1984, C3.

${ }^{83}$ Lois Romano, "Samantha Smith: On to Journalism," Washington Post, 20 January 1984, D4.

${ }^{84}$ Margaret Peacock, "Samantha Smith in the Land of the Bolsheviks: Peace and the Politics of Childhood in the Late Cold War," Diplomatic History, Vol. 43, No. 3 (2019), 441.

85 “Asides; Cecil B. Andropov,” Wall Street Journal, 25 January 1984, 32.

${ }^{86}$ Charles Krauthammer, "Kids' Stuff," The New Republic, 13 February 1984, 10.

${ }^{87}$ Chuck Conconi, "Personalities," Washington Post, 2 February 1984, D3. 
The Eastern Bloc's decision to boycott the 1984 Summer Olympics inspired an epistolary crusade from an American High School in Los Angeles that pinned its hopes on Samantha's initial success. The Los Angeles Olympics Organizing Committee received two thousand hand-written letters from ninth graders to hand over to the Soviet side. One kid wrote: "Don't listen to your leaders who told you that we're going to drug you or something like that. They're just a bunch of \#@!/*." The general opinion was that the games would not be interesting to watch. "Come on," wrote another student, "You guys are our only competition, without you guys the Olympics is nothing." Teachers were more than happy to encourage the campaign. "Hell," said the principal in an interview, "anything we can do to get them to write an effective paragraph before they've left junior high, we feel is having won half the battle in education." 88 Unfortunately, the letters failed to move Konstantin Chernenko's government.

\section{Death}

In 1985, Samantha landed a role playing Robert Wagner's daughter in a television series called Lime Street. Even critics who panned the show admitted that Samantha "took to acting like a natural." 89 After shooting for two weeks in London, Samantha and her father were returning to Lewiston-Auburn Regional Airport in Maine on August 15, 1985, when their Beechcraft 99 airplane crashed short of the runway due to bad weather conditions killing everyone on board. On August 28, 1985, Pravda printed her photograph and an obituary entitled "The Little Voice that Sounded Loudly." Author G. Vasiliev remembered meeting Samantha and her father when they visited the Soviet Embassy School in Washington, DC, earlier that year to drop off a bag of letters from American kids to their Soviet counterparts, as part of a pen-pal campaign that became very popular after Samantha's trip. Arthur Smith told Vasiliev that nine-tenths of the mail that the Smiths received at their home supported their efforts while the rest disapproved and even threatened them. ${ }^{90}$ To this day, the FBI maintains that it has no file on the Smith family. ${ }^{91}$

The Soviet media immediately began to hint at foul play. Television commentator Genrikh Borovik accused the CIA of having planned the accident. ${ }^{92}$ The nightly news program Vremia concluded its report by suggestively noting that

${ }^{88}$ Paul Feldman, "Pupils Send Letters to Soviets About Olympics," Los Angeles Times, 24 May 1984.

${ }^{89}$ Tom Shales, “'Lime Street': A Lemon; ABC's Weary Return for Robert Wagner ABC 's 'Lime Street'," Washington Post, 21 September 1985, C1.

${ }^{90}$ G. Vasiliev, "Golosok, zvuchavshii zvonko," Pravda, 28 August 1985, 5.

${ }^{91}$ William M. Baker, "No Smith File," Los Angeles Times, 24 April 1986, B4. Mr. Baker was Assistant Director of the FBI's Office of Congressional and Public Affairs in 1986. In response to the author's FOIA request, the Bureau responded: "A search of the general indices to the Central Records System did not reveal that the subject of your requests has been the subject of FBI investigation by this office." The Justice Department sent only cross references to the Smith family.

${ }_{92}$ Vsevolod Furtsev, "Kroshka Tsakhes po nevole, Kak rebenok unichtozhil sverkhderzhavu," Nezavisimaia gazeta, 15 July 2004. 
the Beechcraft 99 had one of the safest records in the industry. ${ }^{93}$ Izvestiia's former American correspondent Melor Sturua admitted that he cried when, with his two granddaughters, he watched a program honoring Samantha Smith on Soviet television. She was the "ray and spark" who "refused to see the little devils in the 'Empire of Evil'," Sturua wrote. "Of course our world is not the sun-drenched and sea-stroked 'Artek,' where Samantha's happiest days passed. Nor is it the fateful Auburn-Lewiston Airport, where people and dreams come crashing down." Sturua called on the children of the world to heed Samantha's call to prevent a nuclear catastrophe. ${ }^{94}$ Komsomolskaia pravda reported that they continued to receive letters addressed to Samantha Smith and forwarded them to the US when they could. She was the "girl with the bell that called people to peace. It called adults to remember the mournful bells of Khatyn and Oradura, Lidice and Hiroshima." In a telephone conversation with Komsomolskaia pravda journalists, Jane Smith admitted that she did not know how she would go on living without her husband and Samantha. "I am very touched that in these horrible days Samantha's friends from the Soviet Union remember her and mourn with me. She loved you all, her new Soviet friends, so much, she really believed that there would be peace between our people." 95

The NTSB investigation of the incident found no foul play, but noted that the "absence of key equipment - such as cockpit voice recorders - made it impossible" to "say for sure what caused" the crash. Such accidents, a USA TODAY article noted, "might be prevented if commuter planes had to have the same safety equipment as major airline jets. ${ }^{96}$ The NTSB concluded that a combination of pilot and control tower error led to the crash.

In the US, an NPR reporter praised Samantha for cutting through the cynicism of American politics and Cold War complacency: "Her small action suggested a more universal intent." ${ }^{" 97}$ Another contributor to the Chicago Tribune praised Samantha for her candor "in the years before diplomacy [bred] directness" out of her. ${ }^{98}$ Mikhail Gorbachev sent a telegram and a personal representative to Samantha's funeral, Vladimir Kulagin, who, according to Jane Smith, gave a very sincere and moving eulogy. ${ }^{99}$ The State Department gave him special clearance because Kenebec County, Maine, was one of ten areas off-limits to Soviet citizens. There was nobody present from the US government, although the President and First Lady sent a note of condolences to Jane Smith. In a reply to an Ameri-

93 "Soviets see foul play in Samantha death," Chicago Tribune, 29 August 1985, 5.

${ }^{94}$ Melor Sturua, "Luch i iskra," Izvestiia, 29 August 1985, 5.

95 P. Mikhalev, E. Ovcharenko, "Devochka i kolokol," Komsomolskaia pravda, 27 August 1985, 3 .

${ }_{96}$ Marilyn Adams, “Commuter Airline Safety Questioned," USA TODAY, 1 October 1986.

${ }^{97}$ John Hockenberry, "A girl who broke the barriers," Chicago Tribune, 30 August $1985,23$.

${ }^{98}$ Ellen Goodman, "Tempo; Farewell to Samantha Smith, the child who spoke for us all," Chicago Tribune, 30 August 1985, D2.

${ }^{99}$ Aleksei Anishchuk, “Samolet snizilsia, mem'," Moskovskii komsomolets, $5 \mathrm{Au}-$ gust 2004. 
can angry about the US government not being represented, the White House responded that Ms. Smith's private citizen status did not necessitate a government official at her funeral. ${ }^{100}$

\section{Legacy}

By September 1985, Americans began to suggest exchange programs between Soviet and American schools that would facilitate mutual understanding and ease superpower tensions. Some Americans even suggested "including Chinese school children in such exchanges."101 In October 1985, Jane Smith created the Washington-based Samantha Smith Foundation to promote "international understanding on a personal level" through student exchanges and summer camps for kids ages 11 to 16 . She also joined the advisory committee of the US-Soviet Bridges for Peace organization. The Soviet Peace Committee met Jane Smith halfway with its "Samantha Project," which also facilitated student exchanges. By 1990, the Samantha Smith Foundation brought over its first group of children from the Chernobyl fallout zone, many of them suffering radiation-induced health problems. A year later, the foundation started what is thought to be the first business internship program in the U.S. for university graduates from the Soviet Union (and later its successor states). As declassified documents show, however, the FBI remained suspicious of all exchanges with the USSR because they were so closely curated by the Soviet government through "the new Soviet office set up to help facilitate and coordinate the increased level of exchanges."102 By 1995, the Samantha Smith Foundation's activities declined due to the proliferation of other exchange programs, which it had pioneered. And it is currently dormant. ${ }^{103}$

On the backdrop of the Reagan-Gorbachev summit in Geneva in November 1985, American students in Oceanside High School in California decided to launch a letter-writing campaign with a Soviet high school. "We don't know anyone over there and yet we're willing to kill everyone over there," said one student in an interview. "Maybe if we get to know somebody, find some friends, that will change."104 When a Japanese girl wrote to Mikhail Gorbachev asking for "more and more peace" in the wake of the Geneva Summit, the Japanese press dubbed her "Japan's Samantha Smith," although she received no invitations to tour the Soviet Union. ${ }^{105}$ By December of 1985, televised "bridges" between American and Soviet students started - the first was PBS's "Minnesota-Moscow Children's Space Bridge" in which John Denver participated. Structured around a play dedicated to Samantha Smith, the show culminated with an American boy and Soviet

${ }^{100}$ Letter, M. B. Oglesb, Jr. Assistant to the President to Mr. Senator William S. Cohen, 2 October 1985, ID \#328562, WHORM: Samantha Smith, Ronald Reagan Library.

${ }^{101}$ Juliet Reiter and Robert Lathers, "Samantha Smith's Dream for World Peace," Los Angeles Times, 7 September 1985, A2.

${ }^{102}$ FOIA Request, Section 4 of FBI memo [find out how to cite!].

${ }^{103} \mathrm{http}: / /$ samanthasmith.info/Foundation.htm, accessed on 4 December 2008.

${ }^{104}$ Jennifer Warren, "Teen-Agers Extend Olive Branch to Gorbachev; TEENS: Gorbachev Sent Peace Message," Los Angeles Times, 19 November 1985, SD A1.

105 "Dear M. Gorbachev surprises Japanese girl," Chicago Tribune, 10 January 1986, 4. 
girl singing a duet as a split television screen showed them reaching out to each other across 9,000 miles.

In memory of Samantha, the Soviet Union released a 5-kopek stamp (the cost of mailing a letter within the Soviet Union) in 1985. Samantha also gave her name to the following: a 32.7-karat Siberian diamond, a variety of the violet flower in Lithuania, a street in a small town in Uzbekistan, a 13,000-foot mountain peak in the Caucasus, and an asteroid between Mars and Jupiter. An independent public radio station called Samantha RTV appeared in Moscow in 1990. A private American citizen proposed decommissioning two Minuteman II and SS-11 missiles and exchanging the carcasses that would be incorporated into memorials dedicated to Samantha in the US and the USSR. "History would then record," wrote Doc Blanchard of Long Beach, California, "that the only exchange of missiles between our two countries was a friendly exchange, dedicated to the memory of a brave child." 106 The White House refused the proposal, but the Maine State Legislature erected a statue of Samantha next to the State Library - she is releasing a dove while a bear cub, the symbol of both Maine and Russia, sits at her feet. Moscow dedicated a similar statue, but it was stolen at some point during the 1990 s for the metal's value.

The Soviet Union sent its own "Samantha" to the US in March 1986, but Katia Lycheva's visit did not receive nearly the same coverage as the Smiths' 1983 trip to the Soviet Union, although she did meet President Reagan in the White House for a few minutes. According to declassified FBI documents, she "was no ordinary Soviet but in fact a professional actress... concerned only with promoting the Soviet desire for peace but also with criticizing US moves to 'militarize' space."107 George Will referred to the evolving tradition as "child-mongering."108 However, an American journalist visiting the Republic of Georgia in May 1986 gave Samantha Smith's smiling face painted on a school wall credit for offsetting the images of "a mean-looking Uncle Sam holding blacks in chains" depicted just down the same street. ${ }^{109}$ By 1986, citizen diplomacy became all the rage as Soviets and Americans organized exchange visits for professionals and even biking tours of each other's countries. When in 1999 a ten-year-old Slovenian girl wrote Boris Yeltsin a letter expressing her concern about the possibility of nuclear weapons being used by Russia against NATO during the Yugoslav crisis, the Russian press quickly compared her to Samantha Smith. ${ }^{110}$

Samantha Smith's impact on Soviet citizens, this article's author included, was immediate and direct. "After those four days," remembered Artek camp

${ }^{106}$ Letter, Doc Blanchard to The President, 27 January 1987, ID \#471910, PA002, WHORM: Samantha Smith, Ronald Reagan Library.

${ }^{107}$ FOIA Request, Section 4 of FBI memo [find out how to cite!].

${ }^{108}$ George F. Will, "“We Are the Righteous, We Are ...'," Los Angeles Times, 13 April 1986, D5A.

${ }^{109}$ Richard Cohen, “... And the Legacy of Samantha Smith,” Washington Post, 18 May 1986, F7.

110 "Spokesman Explains Why Yeltsin Answered Girl's Letter," FBIS, 29 May 1999 from ITAR-TASS World Service in English. 
counselor Olga Sakhatova, "my opinion of Americans changed greatly."111 Although mostly forgotten in her home country, Samantha Smith had an impact on her compatriots, too. One American wrote, "Beyond being a role model for the great things children can accomplish, Samantha was much more for me. In two weeks, this little girl fostered understanding where many thought none was possible. Now as we're warned about an 'axis of evil' and instructed to hate a 'homicidal dictator,' I'm more frightened than I was back in the days of the 'evil empire.' Because now I know another generation is growing up with skewed perceptions of other countries, the way I once stereotyped the Soviets."112

Ironically, although the Soviet government conceived Samantha Smith's trip in order to promote a positive image abroad, its greatest impact was on the Soviet Union itself. Millions of Soviet citizens saw a photogenic American family that was not at all threatening. Moreover, the Soviet regime's narrative that it was not a dictatorship bent on expansionism demonstrated the complete collapse of Soviet ideology and the attractiveness of its modernization model by the early 1980sMoscow no longer had any messianic aspirations to sell to the world. It could only convince it that it would not trigger a nuclear holocaust. The fact that Samantha Smith is still remembered in Russia (and the broader post-Soviet space), but is mostly forgotten in the US is further testament that Andropov's original idea of projecting an image to the world was reversed by Samantha projecting herself much more successfully onto Soviet society. Alas, the legacy of soft power operations can often contradict the original intent of their initiators.

\section{About the Author}

Anton Fedyashin is Associate Professor of history at American University in Washington, DC. He received his BA from St. John's College in Annapolis, MD, where he studied the Great Books. He completed an MA at Harvard University in Russian, East European, and Central Asian Studies and went on to defend his doctoral dissertation at Georgetown University. His articles have appeared in the Journal of Cold War Studies; Kritika: Explorations in Russian and Eurasian History; Revista de Instituciones, Ideas y Mercados: The Journal of RussianAmerican Studies; The Historian; The Slavic Review; Perspectives on History; and The Russian Review. He is the author of Liberals under Autocracy: Civil Society and Modernization in Late Imperial Russia, 1866-1904 and is currently writing his second book Superpower Subconscious: The Cold War and the Spy Novel. He regularly contributes analysis of US-Russian relations to media outlets in the US, Europe, and Russia.

111 "O Samante, shokoladkakh, bandikakh i bditel'nykh spetssluzhbakh, Samanta Smit v Arteke-kak eto bylo na samom dele (vospominaniia ee vozhatoi)" http://www.artekovetc.ru/samsmitvoj.html, accessed on 3 December 2008.

${ }^{112}$ Maggie Downs, “A Little Girl Taught Us a Lesson about Peace: Have We Forgotten It?" http://www.commondreams.org/views02/1016-04.htm, accessed on 26 November 2008. 